\title{
Efficiency of Working Capital Management and Firm Value: Evidence From Chinese Listed Firms
}

\author{
Ratnam Vijayakumaran ${ }^{1}$ \\ ${ }^{1}$ Department of Financial Management, University of Jaffna, Sri Lanka \\ Correspondence: Ratnam Vijayakumaran, Department of Financial Management, University of Jaffna, Sri Lanka.
}

Received: December 18, 2018

Accepted: August 19, 2019

Online Published: September 1, 2019

doi:10.5430/ijfr.v10n6p133

URL: https://doi.org/10.5430/ijfr.v10n6p133

\begin{abstract}
This paper examines the relationship between the efficiency of working capital management (WCM) and the firm value, focusing on a large panel of Chinese listed companies. WCM which involves a trade-off between profitability and risk is a very important element of the financial management of the firm. The net trade cycle (NTC) and its components are used to measure efficiency of WCM, while the firm value is measured by the Tobin's Q ratio. The study makes use of the panel data methodology to estimate the regression models. This study reports that the net trade cycle is negatively associated with firm value. More specially, the study finds that firm value is adversely affected by the number of days accounts receivable and inventories, indicating that working capital provides a real opportunity for financial executives to release cash and improve firms' value. The findings of this study are consistent with the idea that managers can enhance firm value by efficiently managing the investment in working capital.
\end{abstract}

Keywords: working capital management, firm value, Tobin's Q, net trade cycle, China

JEL Classification: D22, G31, G32

\section{Introduction}

The working capital management (WCM) is a fundamental aspect of corporate finance which plays a vital role in the survival of the firm, and creating value for its shareholders. WCM attracts a major portion of financial executive's time and attention, yet it receives less attention in the theoretical and empirical literature. Dewing (1941) emphasises that working capital, along with fixed capital, is one of the key elements of the firm. Smith (1978), Berryman (1983) and Dunn and Cheatham (1993) highlight that inefficient WCM / deficient liquidity is the main reason for the failure of most firms, and in particular, small business failures and bankruptcy. The efficient WCM which involves a trade-off between profitability and liquidity risk is particularly important in the global competitive business environment (Lamberson, 1995; Aktas, Croci \& Petmezas, 2015). Since efficient working capital management is crucial to avoid liquidity risk (i.e., likelihood of financial distress/bankruptcy), it has a significant role in the business viability in times of economic downturn such as recent financial crises. For example, the report of KPMG in China (2011) notes that effective WCM has played a very important role in alleviating the effects of the recent financial crisis in China.

Working capital is the difference between current assets and current liabilities (Pass \& Pike, 1984). WCM decisions involve the choice of amount and composition of current asset as well as the financing of these assets. Holding high level of current assets may strengthen liquidity position of the firm but to the detriment of its profitability. According to Padachi (2006), the important function of WCM is to deal effectively with the mismatch between asset and liability and thereby maximize the shareholder wealth. Shin and Soenen (1998) show that the managers can create value for their shareholders by making WCM more efficient. The main objective of the WCM is to maintain an optimal level of working capital that maximizes shareholder wealth. As such, WCM decision which considers a trade-off between efficiency/profitability and risk is, therefore, a very important element of the financial management of the firm.,

Despite the widespread acceptance of the view that efficiency of WCM affects firm value, only a very limited number of empirical studies have focused on the value effect of WCM (Baños-Caballero, García-Teruel, \& Martínez-Solano, 2014). Hence, this study investigates the value effect of WCM using a large panel of listed Chinese 
firms. WCM is particularly important for firm in China, the largest emerging economy with a fast economic growth but a less developed formal financial system where firms have limited access to long-term capital markets. Unlike in developed countries, financial markets in emerging countries are underdeveloped meaning that information and agency problems are particularly pronounced (Deloof, 2003; Morck, Wolfenzon, \& Yeung 2005; Dixon, Guariglia, \& Vijayakumaran, 2015; Vijayakumaran \& Vijayakumaran, 2017a; Vijayakumaran, 2019). Fisman and Love (2003) and Ge and Qiu (2017) show that the use of the important non-formal financial channel (e.g., trade credits) mitigates negative effects of a poorly developed formal financial system with weak creditor protection and imperfect information better than formal lenders. More specially, Ge and Qiu (2017) find that Chinese firms use the informal credit provided by their suppliers to finance growth. Chinese firms rely more on internally generated funds, short-term bank loans, and trade credit to finance their activities (Ding, Guariglia, \& Knight, 2013). Therefore, it becomes vitally important for Chinese firms to manage working capital more efficiently and unlock the fund that may be unnecessarily tied up in working capital to finance the expansion of their operations in the fast growing economy of China.

To examine the extent to which WCM efficiency affects firm value of the Chinese listed companies, we consider the Tobin's Q ratio as a proxy for the firm value and the net trade cycle (NTC), as a chief measure of the working capital management efficiency. Employing a large panel of 9981 firm-year observations of listed companies for the period of 2004-2013, this study finds that the net trade cycle is negatively associated with the Tobin's Q, suggesting that managers can increase their firm value by reducing the net trade cycle to a reasonable minimum. In other words, financial market gives higher valuation to the companies which manage their working capital more efficiently. This paper contributes to the existing literature on the effects of WCM on the firm value by studying the data of Chinese financial markets where the evidence is scarce.

The reminder of the paper proceeds as follows. In Section 2 we review relevant literature and develop hypothesis. The sample, data, model specification, relevant variables and estimation methodology are discussed in Section 3. Section 4 provide descriptive statistics and discusses empirical results. Section 5 concludes the paper.

\section{Literature Review and Hypothesis}

\subsection{Working Capital Management and Company Value}

The significance of efficient working capital management (WCM) is unquestionable. The viability of a business relies on its ability to effectively manage the components of WCM (i.e. receivables, inventory, and payables). Schiff and Lieber (1974), Sartoris and Hill (1983), and Kim and Chung (1990) stress the importance of considering the joint effect of the components of working capital management (i.e., receivable accounts, inventories and payable accounts). As such, the prior empirical research considers NTC/cash conversion cycle (CCC) as a measure of overall working capital management efficiency along with its individual components.

Despite the absence of a single comprehensive theory to explain the link between overall WCM and corporate performance, there is substantial literature linking the components of WCM (i.e., credit policy and inventory management) and firm performance. For example, Lewellen, McConnel and Scott (1980) show that under perfect financial markets, trade credit decisions do not affect firm value. However, the subsequent literature provides several theoretical arguments consistent with the view that the presence of market frictions such asymmetric information and moral hazard problems, etc., make the trade credit and inventories relevant to firm value (see, for example, Brennan et al.,1988; Long, Malitz, \& Ravid 1993; Deloof \& Jegers, 1996; Emery, 1987). Long et al., (1993) develop a model of trade credit which shows that to reduce the asymmetric information between buyer and seller and thus to increase sales, good firms extend trade credit to their clients so that they can verify the quality of product and services prior to payment. In addition, granting trade credit might help to increase a firm's sales, as it can serve as an effective price cut (i.e., an inexpensive source of credit for customers (Brennan, Maksimovics, \& Zechner, 1988; Petersen \& Rajan, 1997); as it strengthens long-term supplier-customer relationships (Ng, Smith, \& Smith, 1999; Wilner, 2000), and as it encourages customers to acquire merchandise at times of low demand (Emery, 1987). Furthermore, trade credit serves as an important supplier selection criterion when it is hard to differentiate products (Shipley \& Davis, 1991; Deloof \& Jegers, 1996). Finally, Emery (1984) point out that granting trade credit is a more profitable short-term investment than marketable securities. Second important element of WCM is management of inventories. Holding larger inventories enables firms to reduce supply costs, hedge against price fluctuations, avoid interruptions in the production process and thus minimize loss of customers and business due to potential stock-outs (Blinder \& Maccini, 1991; Fazzari \& Petersen, 1993).

By contrast, there are also possible adverse effects of keeping excess investment in working capital. For instance, granting generous trade credit and holding larger inventories means that money is locked up in working capital 
which may negatively affect firm performance by eroding the ability of firms to undertake value-enhancing investment projects in the short run (Deloof, 2003; Ek \& Guerin, 2011). Stock holding costs such as warehouse rent, insurance and security expenses also rise as the level of inventory increases (Kim \& Chung, 1990). Furthermore, firms with a greater level of working capital face more interest expenses (Kieschnick, Laplante, \& Moussawi, 2013) and as such, these firms are more likely to experience financial distress and face the threat of bankruptcy.

Most of the prior empirical research focuses on the effect of WCM efficiency on the accounting based performance, for example, focusing on a sample of 1,009 large Belgian non-financial firms over the period of 1992-1996, Deloof (2003) finds no significant effect of Cash conversion cycle on firm profitability. Yet, he finds that gross operating income is negatively related to the number of days accounts receivable, inventories, and accounts payable for Belgian firms, indicating that firms' profitability can be increased by shortening the number of day's inventories and accounts receivable., Banos-Caballero et al. (2010) find a negative association between CCC and operating performance for a sample of small and medium-sized Spanish firms. More recently, by studying a panel of 174 firm-year observations over the period 2011-2016, Vijayakumaran and Vijayakumaran (2017b) find a non-linear relationship (inverted U-shaped) between WCM efficiency (measured by both CCC and NTC) and firm profitability (measured by both ROA and ROE), implying the existence of an optimal level of working capital that maximizes firm's profitability.

However, only a limited number of studies analyse how the efficiency of WCM affects firm value. For example, Shin and Soenen (1998) focus on a COMPUSTAT panel sample of 58,985 firm year observations over the period 1975-1994 and report a strong inverse association between WCM and corporate profitability and risk-adjusted stock returns (a market based measure of performance), suggesting that that firm profitability and shareholder value can be increased by enhancing WCM efficiency. Similarly, by analysing a sample of 172 listed Malaysia companies for the period of 2003- 2007, Mohamad and Saad (2010) find that WCM efficiency variables are significantly and negatively related to firm's market value and profitability. The authors suggest that the importance of efficient WCM should be considered in corporation's strategic and operational planning. Similarly, Vural et al. (2012), focus on a sample of 75 manufacturing companies listed on Istanbul stock exchange market for the period of 2002-2009 and, report that the CCC and the days payable outstanding are negatively associated with firm profitability while WCM does not affect market performance measured by the Tobin's Q. Al-Mwalla (2012) studies a sample of 57 listed companies on Amman stock exchange over the period of 2001-2009 and reports that the conservative policy of WCM is positively related the farms' profitability and value. Abuzayed (2012) finds a negative relationship between CCC and firms' performance measured by both Tobin's Q and accounting based profitability measures, by analysing a panel of 52 non-financial firms listed on Amman stock exchange for the period 2000-2008. By using a large sample of U.S. public corporations for the period 1990 -2006 and applying a valuation framework similar to Faulkender and Wang (2006), Kieschnick et al., (2013) report that for the average firm the incremental dollar invested in NWC is worth less than the incremental dollar held in cash. Using a sample of 192 Malaysian listed companies over the period 1999-2008, Wasiuzzaman (2015) examines the association between WCM efficiency and firm value and the extent to which financing constraints affect this relationship. She finds that while the CCC is negative associated with the firm value, this association is more pronounced in the financially constrained firms indicating that WCM efficiency leads to higher market valuation for financially constrained firms. Most recently, Arachchi, Perera and Vijayakumaran (2017) use a sample of 194 firm year observations on 44 listed companies on the Colombo Stock Exchange (CSE) over the period 2011-2015 and report that CCC is negatively related to Tobin's Q. As for the components of CCC, they find that while the number of days sales outstanding and days sales of inventories are negatively related to the firm value, the number of days payable outstanding is not significantly associated with the firm value.

In the context of China, Gao and Wang (2017) examine whether information about working capital management is useful for financial analysts of Chinese firms, by using a sample of listed companies over the period 2004 to 2014. They find that the efficiency of WCM measured by the cash conversion cycle is positively related to the number of analyst following and analyst forecast accuracy, and negatively related to analyst forecast dispersion. Their findings suggest that analyst following is a potential mechanism through which information about working capital management is reflected in stock price in emerging markets such as China. Although Gao and Wang (2017) identify a channel through which WCM efficiency affect share prices, they do not directly examine the value effect of WCM efficiency.

In sum, the extant literature on the impact of working capital management on firm value is very limited and particularly, in the context of China. Therefore, our study fills this gap by examining the links between the efficiency of WCM and value of Chinese listed firms. 


\subsection{Hypothesis}

The theoretical arguments and majority of prior empirical findings suggest that the shorter the cash net trade cycle, the more efficient the firm is in managing its working capital, and that the efficiency of working capital management increases the firm's profitability and market value (Shin and Soenen, 1998 and Arachchi et al., 2017). The net trade cycle which is a comprehensive measure of working capital management efficiency is closely related to firm valuation and creation of shareholder value. Aa shorter NTC indicates a firm's efficient working capital management which leads to improved cash flow, lower need for external financing, lower financing costs, and consequently enhances financial performance. As such, as Shin and Soenen (1998) point out, the shorter the NTC, the higher the present value of the net cash flow generated by the assets and thus, the higher the value of the firm for its shareholders. Since the net trade cycle is an inverse proxy for the WCM efficiency, we would expect a negative relationship to exist between the NTC and firm value. We, therefore, hypothesize that:

\section{$H_{1}$ : There is a negative relationship between the Net trade cycle and firm value.}

\section{Research Design}

This section discusses the sample, data, our regression model, variables, and estimation methodology.

\subsection{Sample and Dataset}

The data used in this study are obtained from two Chinese databases, namely, the China Stock Market Accounting Database (CSMAR) and Sino-fin for the period of 2004-2013. The sample is composed of publicly listed non-financial firms traded on the Shanghai and Shenzhen stock exchanges. Following the literature, we exclude financial firms from our analysis. To reduce the influence of potential outliers, all variables are trimmed at the upper and lower one-percentiles. After the screening and computation of the variables, we end up with a panel of 9981 firm-year observations on 1651 companies over the period 2004-2013 for our empirical analysis. The panel has an unbalanced structure.

\subsection{Model Specification}

To examine the extent to which WCM efficiency affects firm value, we estimate the following panel data regression model that links Tobin's $Q$ with WCM efficiency (NTC) and a set of firm characteristics:

$$
\mathrm{TQ}_{\mathrm{it}}=\beta_{0}+\beta_{1} \mathrm{NTC}_{\mathrm{it}}+\beta_{2} \mathrm{SIZE}_{\mathrm{it}}+\beta_{3} \mathrm{LEV}_{\mathrm{it}}+\beta_{4} \mathrm{SGR}_{\mathrm{it}}+\beta_{5} \mathrm{LIQ}_{\mathrm{it}}+\beta_{6} \mathrm{FAG}_{\mathrm{it}}+\mathrm{v}_{\mathrm{i}}+\mathrm{v}_{\mathrm{t}}+\mathrm{v}_{\mathrm{j}}+\mathrm{v}_{\mathrm{r}}+\varepsilon_{\mathrm{it}}
$$

Where $i$ indexes firms, $t$ years. Table 1 provides definitions and expected signs for all variables used in this paper. The error term in Equation (1) is made up of five components: $v_{i}$ is a firm-specific effect; $v_{t}$, is a time-specific effect, which we control for by including time dummies capturing business cycle effects; $v_{j}$, an industry-specific effect, which we take into account by including industry dummies; $v_{r}$, a region-specific effect, which we control for by including a full-set of regional dummies. Finally, $\varepsilon_{i t}$ is an idiosyncratic component.

In addition, we also estimate equation (1) by including the components of $N T C$, namely, the number of days accounts receivable, the number of days inventory and the number of days accounts payable on firm value, respectively in isolation in place of NTC to see the effects of the components of NTC on the firm value.

\subsection{Variables}

\subsubsection{Firm Value}

In line with the previous literature, the Tobin's $Q$ ratio is used to measure the firm value; which captures investors' forward-looking valuation perceptions. The Tobin's $Q$ is the ratio of the market value of a company's assets (which is measured by the market value of its shares and book value of debt) scaled by the book value of the company's assets.

\subsubsection{WCM Efficiency Variables}

The purpose of this study is to examine the relationship between WCM efficiency and firm value of listed companies in the context of China. To this end, the main independent variable considered here is the length of the firm's net trade cycle (denoted by NTC) which the finance literature has used as a comprehensive measure of firms' WCM efficiency (Shin \& Soenen, 1998, Baños-Caballero et al., 2014, Vijayakumaran \& Vijayakumaran, 2017b). The CFO magazine and the profession bodies have also widely identified the length of the firm's NTC (also known as working capital days -WCD) as the measure of WCM efficiency. The Net trade cycle is the sum of number of days accounts receivable plus number of days inventory minus number of days accounts payable. The components of $N T C$ are calculated as follows. Number of days that sales are outstanding (denoted by $D S O$ ) is calculated as a ratio of accounts receivable times 365 divided by sales. Number of day's inventories (denoted by DIO) is calculated as a ratio of inventories times 365 divided by sales. Number of days that payables are outstanding (denoted by DPO) is accounts payable times 365 
divided by sales. The NTC thus provides an estimate for additional financing needs associated with working capital expressed as a function of the projected sales growth (Shin \& Soenen, 1998). Following the literature, we predict a negative association between DSO (a measure of accounts receivable policy) and DIO and firm value whereas a positive association between $D P O$ and firm value.

\subsubsection{Control Variables}

Following previous studies, we include the following controls in the regression models to control for a set of firm-specific characteristics that are likely to be correlated with firm value: firm size (SIZE) which is measured by the natural logarithm of real sales); sales growth $(S G R)$ which we measure by current year's real sales minus previous year's real sales divided by previous year's real sales; leverage which is proxied by the ratio of total debt to total assets; liquidity which is measured by the ratio of current assets to current liabilities and firm age (AGE) which we measure by using the natural logarithm of the number of years since the establishment of the firm.

Table 1. Measurement of variables

\begin{tabular}{|c|c|c|c|}
\hline Variables & Acronyms & Measurement & $\begin{array}{l}\text { Expected } \\
\text { relationship } \\
\text { with firm value }\end{array}$ \\
\hline \multicolumn{4}{|l|}{ Firm value } \\
\hline Tobin's Q & $T Q$ & $\begin{array}{l}\text { (Market value of equity }+ \text { book value of } \\
\text { liabilities)/ book value of total assets }\end{array}$ & \\
\hline \multicolumn{4}{|l|}{ WCM Variables } \\
\hline Days Sales Outstanding & DSO & (Accounts receivables/sales)*365 & - \\
\hline Days Inventories On-Hand & $\mathrm{DIO}$ & (Inventories/ sales)*365 & - \\
\hline Days Payables Outstanding & $D P O$ & (Accounts payables/ sales)*365 & + \\
\hline Net trade cycle & $N T C$ & $\begin{array}{l}\text { Aggregation of inventory, receivables and } \\
\text { payables days (DSO + DIO - DPO) }\end{array}$ & - \\
\hline \multicolumn{4}{|l|}{ Control Variables } \\
\hline Firm size & $S I Z E$ & The natural logarithm of real sales & $+/-$ \\
\hline Leverage & $L E V$ & Total debt divided by total assets & $+/-$ \\
\hline Sales growth & $S G R$ & $\begin{array}{l}\text { (This year's sales }- \text { previous year's } \\
\text { sales)/previous year's sales }\end{array}$ & + \\
\hline Liquidity & LIQTY & $\begin{array}{l}\text { The ratio of current assets to current } \\
\text { liabilities }\end{array}$ & + \\
\hline Firm age & FAGE & $\begin{array}{l}\text { The natural logarithm of the number of years } \\
\text { since the establishment of the firm }\end{array}$ & $+/-$ \\
\hline Year dummies & $v_{t}$ & Year dummies for the years 2005 to 2013 . & \\
\hline Industry dummies & $v_{j}$ & $\begin{array}{l}\text { Dummies for the following four industrial } \\
\text { groups based on the CSMAR B } \\
\text { classification: Properties, Conglomerates, } \\
\text { Industry, Commerce. Utilities and financial } \\
\text { industries are excluded. }\end{array}$ & \\
\hline Regional dummies & $v_{r}$ & $\begin{array}{l}\text { Dummies indicating whether the firm is } \\
\text { located in the Coastal, Western, or Central } \\
\text { region of China }\end{array}$ & \\
\hline
\end{tabular}




\subsection{Estimation Methodology}

Most of the prior studies from developing countries that examines the relation between WCM and corporate performance use pooled OLS (Ordinary Least Square) regressions. However, the pooled OLS regression does not take into account the potential endogeneity arising from the unobserved firm heterogeneity, for example, managerial expertise which affects both the firm's WCM efficiency and its value. Thus, OLS estimator is more likely to provide biased estimates of the coefficients of our WCM variables. Therefore, we use fixed effects regression which enable us to control for the possibility that endogeneity arises from omitted unobserved factors. We use the Hausman specification test to decide whether fixed effect method (FEM) or random effect method (REM) is econometrically a more appropriate approach to our data. Highly significant Hausman Chi-Square test statistics reveal systematic differences in coefficients between both models, which indicate highly significant firm-specific effects. Thus, FEM provides better specification of our model relative to REM.

\section{Empirical Results}

This section provides discussion of empirical results obtained from correlation and regression analysis.

4.1 Summary Statistics

Table 2. Summary statistics

\begin{tabular}{llllll}
\hline & Mean & Median & Std. Dev. & Min & Max \\
\hline Tobin's Q $(T Q)$ & 1.721 & 1.483 & 0.970 & 0.804 & 6.818 \\
\hline Net trade cycle $(N T C)$ & 136.616 & 87.382 & 166.988 & -82.282 & 1390.238 \\
\hline Days sales outstanding $(D S O)$ & 65.565 & 46.221 & 68.813 & 0.040 & 564.152 \\
\hline Days inventories on-hand $(D I O)$ & 123.012 & 73.223 & 160.347 & 1.835 & 1258.688 \\
\hline Days payables outstanding $(D P O)$ & 51.961 & 45.179 & 32.370 & 2.981 & 194.883 \\
\hline Firm size $(S I Z E)$ (billion $R M B)$ & 1.408 & .531 & 2.852 & 0.264 & 19.478 \\
\hline Leverage $($ LEV & 0.518 & 0.519 & 0.250 & 0.073 & 1.093 \\
\hline Sales growth $(S G R)$ & 0.149 & 0.099 & 0.245 & -0.535 & 2.909 \\
\hline Liquidity (LIQ) & 1.490 & 1.221 & 1.063 & 0.302 & 8.946 \\
\hline Firm age (FAG) & 12.948 & 12.000 & 4.058 & 1.000 & 29.000 \\
\hline
\end{tabular}

Notes: Variable definitions are provided in the Table 1.

Table 2 provides summary statistics for the variables used in this study. The pooled mean and median of the Tobin's $\mathrm{Q}(T Q)$ is 1.72 and 1.48 , respectively. The net trade cycle (NTC) is quite long, with mean (median) NTC of 136.62 days (87.38 days). This is markedly longer than the average (median) NTC of 90 days (86 days), reported in Shin and Soenen (1998) for the US firms over the period the 1975-1994. Firms receive payment from their credit sales after on average of 65.57 days with a median of 46.22 days. It takes on average 123 days (median is 73.22 days) to sell inventory. Firms pay their suppliers after 51.96 days on average, (median is 45.18 days). The large disparity between mean and median values for the NTC and its components indicates the dramatic variation in turnover ratios among the sample firms.

Turning to the control variables which we include in the regressions, the mean and median values of firm size proxied by the real sales are about 1.41 billion RMB and .531 billion RMB, respectively. The average debt ratio which is measured by the ratio of total debt to total assets is given by $51.8 \%(51.9 \%)$, indicating that about $52 \%$ of the sample companies' assets are financed by debt capital. The average sales growth of the sample firms, measured as changes in real sales, is $14.9 \%(10 \%)$. The average liquidity, proxied by the ratio of current liabilities over current assets, is 1.49 (1.22). Finally, the mean value of firm age, peoxied by the number of years since the establishment of the company, is about 13 years (12 years)

These descriptive statistics demonstrate that the sample used in this research is comparable to those used in the previous studies on working capital of Chinese listed firms (e.g., Singhania and Mehta, 2017). 


\subsection{Correlation Analysis}

Table 3 presents the Pearson correlation coefficients for the pairs of variables used in this study. We observe that $N T C$ is significantly and negative associated with Tobin's $\mathrm{Q}(T Q)$ which is in line with the prediction that an increase in time lag in net trade cycle will adversely affect the value of a firm. Looking at the components of NTC, the negative correlation which we see between the day's sales outstanding (DSO) and $T Q$ indicates a long debtor's collection period (i.e., a firm's inefficiency in collecting payment from debtors) would decrease the market value of a company. Similarly, day's inventories on hand $(D I O)$ also have a significant negative association with the firm value. Finally, it is worth noticing that the number of days payables outstanding $(D P O)$ is significantly negatively related to firm value.

As for the control variables, the firm size is negatively associated with TQ, suggesting that small firms tend to have higher market valuation. Furthermore, the significant negative correlation between the ratio of total debt to total assets and $T Q$ demonstrate that the market perceives a higher level of financial leverage as detrimental to shareholders' interest as it increases the financial risk of a firm. Liquidity and firm age have positive and significant relation with firm value. Finally, Table 3 suggests that given that the observed correlation coefficients are relatively low, multicollinearity should not be a serious problem in our study.

Table 3. Pearson correlation matrix

\begin{tabular}{|c|c|c|c|c|c|c|c|c|c|c|}
\hline & TQ & NTC & DSO & DIO & DPO & SIZE & LEV & SGR & $L I Q$ & $L I Q$ \\
\hline$T Q$ & 1.00 & & & & & & & & & \\
\hline NTC & $-0.07 *$ & 1.00 & & & & & & & & \\
\hline$D S O$ & $-0.04 *$ & $0.37 *$ & 1.00 & & & & & & & \\
\hline $\mathrm{DIO}$ & $-0.06 *$ & $0.92 *$ & $0.03 *$ & 1.00 & & & & & & \\
\hline$D P O$ & $-0.04 *$ & $0.21 *$ & $0.36^{*}$ & $0.26^{*}$ & 1.00 & & & & & \\
\hline$S I Z E$ & $-0.23 *$ & $-0.28 *$ & $-0.41 *$ & $-0.14 *$ & $-0.13 *$ & 1.00 & & & & \\
\hline$L E V$ & $-0.24 *$ & $0.06^{*}$ & $-0.04 *$ & $0.13^{*}$ & $0.24 *$ & $0.33 *$ & 1.00 & & & \\
\hline$S G R$ & $0.06^{*}$ & 0.02 & $-0.09 *$ & $0.06 *$ & -0.02 & $0.12 *$ & $0.07 *$ & 1.00 & & \\
\hline$L I Q$ & $0.20 *$ & $0.15^{*}$ & $0.09 *$ & $0.09 *$ & $-0.09 *$ & $-0.23^{*}$ & $-0.65^{*}$ & 0.00 & 1.00 & \\
\hline$F A G$ & $0.09 *$ & $0.03 *$ & $-0.14 *$ & $0.09 *$ & 0.01 & $0.14 *$ & $0.20 *$ & $-0.04 *$ & $-0.20 *$ & 1.00 \\
\hline
\end{tabular}

Notes: * denotes statistical significance at the 5\% level or more. Variable definitions are provided in the Table 1.

\subsection{Multivariate Analysis}

\subsubsection{Panel OLS Regression Results}

We use multivariate analysis to isolate the effect of WCM on firm value. The pooled OLS regressions of the impact of WCM efficiency on firm value [see Eq. (1)] are reported in Table 4. Column 1 presents estimation results of the regression of Tobin's $\mathrm{Q}(T Q)$ on net trade cycle $(N T C)$ and a set of controls including firm size, leverage, sales growth, liquidity, firm age and a set of dummies for year, industry and regional effects. In addition, we replicate Eq. (1) with the components of NTC, namely, the number of day's accounts receivable, the number of day's inventory and the number of day's accounts payable, respectively, instead of NTC to test the effect of these variables on firm value and report the results in Columns 2-4 of Table 4.

As we can see in Column 1 of Table 4, the estimated coefficient of NTC is negatively significant at the $1 \%$ level, supporting our hypothesis $H_{l}$. Since the $N T C$ is an inverse proxy for the efficiency of WCM, this result provides strong evidence for a negative relation between $N T C$ and firm value (or equivalently, a positive relationship between the efficiency of WCM and firm value), implying that the market recognizes the firms that manage more efficiently their working capital and these firms are valued with higher Tobin's Q ratios, as predicted. This result is in line with the findings reported in Abuzayed (2012), Wasiuzzaman (2015) and Arachchi et al. (2017).

Furthermore, as it can be observed in Columns 2-4 of the Table 4, the coefficient of the days sales outstanding (DSO) and day's inventories on hand (DIO) are significantly negative (at the $1 \%$ level), as expected. These results are in line with findings of previous empirical works (e.g., Wasiuzzaman, 2015; Arachchi et al., 2017). 
It is worth noticing that the coefficient associated with the number of days accounts payable (DPO) is negatively significant at the $1 \%$ level. This finding is consistent with the findings of Deloof (2003) who reports a negative association between gross operating income and the number of days payables outstanding (DPO). As in Deloof (2003), this result can be interpreted as less profitable firms which wait longer to pay their bills are valued with lower Tobin's Q ratios.

Table 4. Panel OLS: the relationship between WCM and firm value

\begin{tabular}{|c|c|c|c|c|}
\hline Regression Models & 1 & 2 & 3 & 4 \\
\hline$N T C$ & $\begin{array}{l}-.0 .056 * * * \\
(-6.67)\end{array}$ & & & \\
\hline DSO & & $\begin{array}{l}-0.055^{* * * *} \\
(-3.09)\end{array}$ & & \\
\hline$D I O$ & & & $\begin{array}{l}-0.056^{* * *} \\
(-6.71)\end{array}$ & \\
\hline$D P O$ & & & & $\begin{array}{l}-0.112 * * * \\
(-2.96)\end{array}$ \\
\hline SIZE & $\begin{array}{l}-0.185 * * * \\
(-14.61)\end{array}$ & $\begin{array}{l}-0.176 * * * \\
(-13.67)\end{array}$ & $\begin{array}{l}-0.175 * * * \\
(-14.44)\end{array}$ & $\begin{array}{l}-0.170^{* * *} \\
(-14.19)\end{array}$ \\
\hline$L E V$ & $\begin{array}{l}-0.608 * * * \\
(-6.14)\end{array}$ & $\begin{array}{l}-0.683 * * * \\
(-6.98)\end{array}$ & $\begin{array}{l}-0.615 * * * \\
(-6.23)\end{array}$ & $\begin{array}{l}-0.655^{* * *} \\
(-6.70)\end{array}$ \\
\hline$S G R$ & $\begin{array}{l}0.140 * * * \\
(5.03)\end{array}$ & $\begin{array}{l}0.136 * * * \\
(4.80)\end{array}$ & $\begin{array}{l}0.142 * * * \\
(5.13)\end{array}$ & $\begin{array}{l}0.137 * * * \\
(4.83)\end{array}$ \\
\hline$L I Q$ & $\begin{array}{l}0.033^{* *} \\
(2.13)\end{array}$ & $\begin{array}{l}0.019 \\
(1.29)\end{array}$ & $\begin{array}{l}0.029^{*} \\
(1.92)\end{array}$ & $\begin{array}{l}0.016 \\
(1.13)\end{array}$ \\
\hline$F A G$ & $\begin{array}{l}0.139 * * * \\
(4.50)\end{array}$ & $\begin{array}{l}0.130 * * * \\
(4.23)\end{array}$ & $\begin{array}{l}0.140 * * * \\
(4.57)\end{array}$ & $\begin{array}{l}0.130 * * * \\
(4.24)\end{array}$ \\
\hline Constant & $\begin{array}{l}4.752 * * * \\
(20.04)\end{array}$ & $\begin{array}{l}4.635 * * * \\
(18.83)\end{array}$ & $\begin{array}{l}4.530 * * * \\
(19.86)\end{array}$ & $\begin{array}{l}4.495 * * * \\
(19.65)\end{array}$ \\
\hline Year Fixed Effects & Yes & Yes & Yes & Yes \\
\hline Industry Fixed Effects & Yes & Yes & Yes & Yes \\
\hline Regional Fixed Effects & Yes & Yes & Yes & Yes \\
\hline $\operatorname{Adj} R^{2}$ & 0.4131 & 0.4080 & 0.4123 & 0.4082 \\
\hline F-statistic & 205.84 & 204.57 & 206.47 & 203.85 \\
\hline Prob (F-statistic) & 0.000 & 0.000 & 0.000 & 0.000 \\
\hline
\end{tabular}

Notes: As in Shin and Soenen (1998), NTC and its components are divided by 100. Asterisks denote statistical significance at the $1 \%(* * *), 5 \%(* *)$, or $10 \%(*)$ level, respectively. The t-statistics which are computed using cluster robust slandered error (clustered at the firm level) are reported in the parentheses. Variable definitions are provided in the Table 1. Industry Fixed Effects, Year Fixed Effects, Regional Fixed Effects denote whether calendar year fixed effects, industry specific fixed effects and region specific fixed effects are included in the specification.

Generally, the results of pooled OLS regressions indicate that managers can increase the market value of their firms by making WCM more efficient, particularly by reducing the two levers of NTC, namely, the number of day's accounts receivable and inventories.

Turning to the control variables, we note that the coefficient of firm size (SIZE) is negatively significantly related to TQ in all the regressions, implying that large firms experience more agency problem and are thus negatively related to firm value. This result is in line with the finding of $\mathrm{Li}, \mathrm{Lu}$, Mittoo, and Zhang (2015). The coefficient of leverage is negative and statistically significant at the $5 \%$ level, demonstrating that the increase in financial risk associated 
with the leverage is not appealing to investors (e.g, Arachchi et al., 2017). Finally, sales growth $(S G R)$ and firm age exhibit a positive and significant relation to firm value. Finally, liquidity is significantly positively related to firm value in two regressions.

\subsubsection{Fixed Effects Regression Results}

Table 5 reports the results of fixed effects regressions [see Eq. (1)]. Column 1 of Table 5 presents estimation results of the regression of Tobin's $\mathrm{Q}(T Q)$ on net trade cycle $(N T C)$ and a set of controls including firm size, leverage, sales growth, liquidity, firm age and a set of dummies for year, industry and regional effects. Additionally, we replicate Eq. (1) with the components of $N T C$, namely, the number of day's accounts receivable, the number of days inventory and the number of days accounts payable, respectively, instead of $N T C$ to test the effect of these variables on firm value and report the results in Columns 2-4 of Table 5.

Table 5. Fixed effects regression: the relationship between WCM and firm value

\begin{tabular}{|c|c|c|c|c|}
\hline Regression Model & 1 & 2 & 3 & 4 \\
\hline NTC & $\begin{array}{l}-0.114 * * * \\
(-11.13)\end{array}$ & & & \\
\hline DSO & & $\begin{array}{l}-0.165^{* * * *} \\
(-8.18)\end{array}$ & & \\
\hline DIO & & & $\begin{array}{l}-0.099 * * * \\
(-8.94)\end{array}$ & \\
\hline$D P O$ & & & & $\begin{array}{l}-0.229 * * * \\
(-5.28)\end{array}$ \\
\hline SIZE & $\begin{array}{l}-0.311 * * * \\
(-11.84)\end{array}$ & $\begin{array}{l}-0.275^{* * * *} \\
(-10.57)\end{array}$ & $\begin{array}{l}-0.306^{* * *} \\
(-11.60)\end{array}$ & $\begin{array}{l}-0.283 * * * \\
(-10.75)\end{array}$ \\
\hline$L E V$ & $\begin{array}{l}-0.573 * * * \\
(-4.85)\end{array}$ & $\begin{array}{l}-0.696 * * * \\
(-5.92)\end{array}$ & $\begin{array}{l}-0.604 * * * \\
(-5.08)\end{array}$ & $\begin{array}{l}-0.662 * * * \\
(-5.51)\end{array}$ \\
\hline$S G R$ & $\begin{array}{l}0.086^{* * * *} \\
(3.46)\end{array}$ & $\begin{array}{l}0.083 * * * \\
(3.29)\end{array}$ & $\begin{array}{l}0.103 * * * \\
(4.14)\end{array}$ & $\begin{array}{l}0.103 * * * \\
(4.10)\end{array}$ \\
\hline$L I Q$ & $\begin{array}{l}-0.043 * * \\
(-2.39)\end{array}$ & $\begin{array}{l}-0.061 * * * \\
(-3.37)\end{array}$ & $\begin{array}{l}-0.051 * * * \\
(-2.81)\end{array}$ & $\begin{array}{l}-0.070 \text { *** } \\
(-3.85)\end{array}$ \\
\hline$F A G$ & $\begin{array}{l}0.949 * * * \\
(7.33)\end{array}$ & $\begin{array}{l}1.005^{* * * *} \\
(7.69)\end{array}$ & $\begin{array}{l}0.882 * * * \\
(6.79)\end{array}$ & $\begin{array}{l}0.903 * * * \\
(6.91)\end{array}$ \\
\hline Constant & $\begin{array}{l}5.483 * * * \\
(9.23)\end{array}$ & $\begin{array}{l}4.801 \text { *** } \\
(8.11)\end{array}$ & $\begin{array}{l}5.422 * * * \\
(9.07)\end{array}$ & $\begin{array}{l}5.023 * * * \\
(8.38)\end{array}$ \\
\hline Firm fixed effects & Yes & Yes & Yes & Yes \\
\hline Year fixed effects & Yes & Yes & Yes & Yes \\
\hline Regional fixed effects & Yes & Yes & Yes & Yes \\
\hline $\operatorname{Adj} R^{2}$ & 0.5158 & 0.5106 & 0.5119 & 0.5071 \\
\hline F-statistic & 432.01 & 423.18 & 425.46 & 417.37 \\
\hline Prob (F-statistic) & 0.000 & 0.000 & 0.000 & 0.000 \\
\hline
\end{tabular}

Notes: As in Shin and Soenen (1998), NTC and its components are divided by 100. Asterisks denote statistical significance at the $1 \%(* * *), 5 \%(* *)$, or $10 \%(*)$ level, respectively. The t-statistics which are computed using cluster robust slandered error (clustered at the firm level) are reported in the parentheses. Variable definitions are provided in the Table 1. Industry Fixed Effects, Year Fixed Effects, Regional Fixed Effects denote whether calendar year fixed effects, industry specific fixed effects and region specific fixed effects are included in the specification. 
First, the coefficient associated with $N T C$ is negatively significant at the $1 \%$ level, providing support to our hypothesis (H1). This result once again confirms that $N T C$ has a strong negative relation with firm value. Additionally, Columns 2-4 of the Table 5 show that the coefficients of the days accounts receivable (DSO), days inventories on hand $((D I O)$ and the days payables outstanding $(D P O)$ are negatively significant at the $1 \%$ level. These results suggest that firm with an inefficient working capital management valued by the market with a lower Tobin's Q. Looking at the control variables, we observe that the results ae qualitatively similar to the results of the pooled OLS regressions reported in the Table 4 except liquidity which displays negatively significant coefficients in all the regressions in Table 5.

Finally, as in Deloof (2003) we also note that the adjusted 'within' $\mathrm{R}^{2} \mathrm{~s}$ of the fixed effects regressions are higher than that of the panel OLS regressions, suggesting a relatively higher portion of the variations in firm value comes from time-series variation than between firms.

\section{Conclusions}

The working capital management involves a trade-off between profitability and liquidity risk and thus it affects the market value of the firm. Although a large body of prior empirical research reports that firm value is influenced by the efficient WCM, only a limited of empirical works focus on the impacts of WCM efficiency on the firm value. Thus, this study examines the value effect of WCM efficiency in the context of China.

Using a panel data set of firm-year observations of Chinese listed firms over the period 2004-2013, we find that the net trade cycle is negatively related to the firm value proxied by the Tobin's Q ratio. Our results suggest that Chinese listed companies can increase their market valuation by efficiently managing the investment in working capital, and hence enhance shareholder wealth. Yet, considering the negative association between the number of days accounts payables and the firm value, the true benefits of shortening the net trade cycle come from reduction in assets rather than by delaying the payments to suppliers. In other words, because of too much cash being locked up in inventories or receivables, the cost of financing these elements of NTC can erode profit margins. Therefore, this study suggests that Chinese listed firms should pay more attention on reducing the main two levers of net trade cycle, namely, the number of day's accounts receivable and inventories to a reasonable minimum to generate shareholder value.

\section{References}

Abuzayed, B. (2012). Working capital management and firm's performance in emerging markets: the case of Jordan. International Journal of Managerial Finance, 8(2), 155-179. https://doi.org/10.1108/17439131211216620

Aktas, N., Croci, E., \& Petmezas, D. (2015). Is working capital management value-enhancing? Evidence from firm performance and investments. Journal of Corporate Finance, 30, 98-113. https://doi.org/10.1016/j.jcorpfin.2014.12.008

Al-Mwalla, M. (2012). The impact of working capital management policies on firm's profitability and value: The case of Jordan. International Research Journal of Finance and Economics, 85, 147-153. Retrieved from http://connection.ebscohost.com/c/articles/74203445

Arachchi, H. A. N., Perera, P., \& Vijayakumaran, R. (2017). The impact of working capital management on firm value: Evidence from frontier market. Asian Journal of Finance \& Accounting, 9(2), 399-413. https://doi.org/10.5296/ajfa.v9i2.12449

Banos-Caballero, S., García-Teruel, P. J., \& Martínez-Solano, P. (2010). Working capital management in SMEs. Accounting and Finance, 50(3), 511-527. https://doi.org/10.1111/j.1467-629X.2009.00331.x

Baños-Caballero, S., García-Teruel, P. J., \& Martínez-Solano, P. (2014). Working capital management, corporate performance, and financial constraints. Journal of Business Research, 67(3), 332-338. https://doi.org/10.1016/j.jbusres.2013.01.016

Berryman, J. (1983). Small business failure and bankruptcy: A survey of the literature. European Small Business Journal, 1(4), 47-59. https://doi.org/10.1177/026465608300100404

Blinder, A. S., \& Maccini, L. J. (1991). The resurgence of inventory research: What have we learned?. Journal of Economic Surveys, 5, 291-328. https://doi.org/10.1111/j.14676419.1991.tb00138.x

Brennan, M. J., Maksimovics, V., \& Zechner, J. (1988). Vendor financing. The Journal of Finance, 43(5), 1127-1141. https://doi.org/10.1111/j.1540-6261.1988.tb03960.x

Deloof, M. (2003). Does working capital management affect profitability of Belgian firms?. Journal of Business Finance \& Accounting, 30(3-4), 573-588. https://doi.org/10.1111/1468-5957.00008 
Deloof, M., \& Jegers, M. (1996). Trade credit, product quality, and intragroup trade: Some European evidence. Financial Management, 33-43. https://www.jstor.org/stable/3665806

Dewing, A. S. (1941). The financial policy of corporations (4th ed.). The Ronald Press Company, New York. Retrieved from https://www.jstor.org/stable/2555961

Ding, S., Guariglia, A., \& Knight, J. (2013). Investment and financing constraints in China: Does working capital management make a difference?. Journal of Banking \& Finance, 37(5), 1490-1507. https://doi.org/10.1016/j.jbankfin.2012.03.025

Dixon, R., Guariglia, A., \& Vijayakumaran, R. (2017). Managerial ownership, corporate governance and firms' exporting decisions: Evidence from Chinese listed companies. The European Journal of Finance, 23(7-9), 802-840. http://doi/abs/10.1080/1351847X.2015.1025990

Dunn, P., \& Cheatham, L. (1993). Fundamentals of small business financial management for start-up, survival, growth, and changing economic circumstances. Managerial Finance, 19, 1-13. https://doi.org/10.1108/eb013737

Emery, G. (1984). A pure financial explanation for trade credit. Journal of Financial and Quantitative Analysis, 19, 271-285. https://doi.org/10.2307/2331090

Eswaran, V. (2015). Shareholders wealth effects of rights and bonus issues: Evidence from Sri Lanka. International Journal of Accounting and Business Finance, 1(2), 1-13. Retrieved from https://papers.ssrn.com/sol3/papers.cfm?abstract_id=2733950

Fazzari, S. M., \& Petersen, B. C. (1993). Working capital and fixed investment: new evidence on financing constraints. The RAND Journal of Economics, 328-342. Retrieved from https://www.jstor.org/stable/2555961

Fisman, R., \& Love, I. (2003). Trade credit, financial intermediary development and industry growth. The Journal of Finance, 58(1), 353-374. https://doi.org/10.1111/1540-6261.00527

Gao, J., \& Wang, J. (2017). Is working capital information useful for financial analysts? Evidence from China. Emerging Markets Finance and Trade, 53(5), 1135-1151. https://doi.org/10.1080/1540496X.2016.1278166

Kieschnick, R., Laplante, M., \& Moussawi, R. (2013). Working capital management and shareholders' wealth. Review of Finance, 17(5), 1827-1852. https://doi.org/10.1093/rof/rfs043

Kim, Y. H., \& Chung, K. H. (1990). An integrated evaluation of investment in inventory and credit: A cash flow approach. Journal of Business Finance \& Accounting, 17(3), 381-389. https://doi.org/10.1111/j.1468-5957.1990.tb01192.x

KPMG China. (2011). Cash matters. Cash and working capital management in China. Retrieved from https://www.kpmg.de/docs/CashMatters.pdf

Lamberson, M. (1995). Changes in working capital of small firms in relation to changes in economic activity. American Journal of Business, 10(2), 45-50. https://doi.org/10.1108/19355181199500015

Lewellen, W., McConnel, J., \& Scott, J. (1980). Capital market influences on trade credit policies. Journal of Financial Research, 3, 105-113. https://doi.org/10.1111/j.1475-6803.1980.tb00043.x

Li, K., Lu, L., Mittoo, U. R., \& Zhang, Z. (2015). Board independence, ownership concentration and corporate performance-Chinese evidence. International Review of Financial Analysis, 41, 162-175. https://doi.org/10.1016/j.irfa.2015.05.024

Long, M. S., Malitz, I. B., \& Ravid, S. A. (1993). Trade credit, quality guarantees and product marketability. Financial Management, 22, 117-127. Retrieved from https://www.jstor.org/stable/3665582

Mohamad, N. E. A. B., \& Saad, N. M. B. (2010). Working capital management: The effect of market valuation and profitability in Malaysia. International Journal of Business and Management, 5(11), 140-147. https://doi.org/10.5539/ijbm.v5n11p140

Morck, R., Wolfenzon, D., \& Yeung, B. (2005). Corporate governance, economic entrenchment, and growth. Journal of Economic Literature, 43(3), 655-720.

Ng, C. K., Smith, J. K., \& Smith, R. L. (1999). Evidence on the determinants of credit terms used in interfirm trade. Journal of Finance, 54, 1109-1129. https://doi.org/10.1111/0022-1082.00138

Padachi, K. (2006). Trends in working capital management and its impact on firms' performance: an analysis of 
Mauritian small manufacturing firms. International Review of Business Research Papers, 2(2), 45-58. Retrieved from http://citeseerx.ist.psu.edu/viewdoc/download?doi=10.1.1.475.2653

Pass, C. L., \& Pike, R. H. (1984). An overview of working capital management and corporate financing. Managerial Finance, 10(3), 1-11. https://doi.org/10.1108/eb027318

Petersen, M., \& Rajan, R. (1997). Trade credit: Theories and evidence. Review of Financial Studies, 10, 661-691. https://doi.org/10.1093/rfs/10.3.661

Sartoris, W., \& Hill, N. (1983). Cash and working capital management. Journal of Finance, 38, 349-360.

Schiff, M., \& Lieber, Z. (1974). A model for the integration of credit and inventory management. Journal of Finance, 29, 133-140. Retrieved from https://www.jstor.org/stable/2978219

Shin, H. H., \& Soenen, L. (1998). Efficiency of working capital and corporate profitability. Financial Practice and Education, 8(2), 37-45.

Singhania, M., \& Mehta, P. (2017). Working capital management and firms' profitability: evidence from emerging Asian countries. South Asian Journal of Business Studies, 6(1), 80-97.

Smith, K. V. (1978). Reading on the management of working capital (pp. 3-21). West Publishing Company.

Vijayakumaran, R. (2019). Agency costs, ownership, and internal governance mechanisms: Evidence from Chinese listed companies. Asian Economic and Financial Review, 9(1), 133-154. https://doi.org/10.18488/journal.aefr.2019.91.133.154

Vijayakumaran, R., \& Vijayakumaran, S. (2017a). Institutional reforms and development of corporate governance and banking system in china. Asian Journal of Finance \& Accounting, 9(2), 352-368. https://doi.org/10.5296/ajfa.v9i2.12382

Vijayakumaran, R., \& Vijayakumaran, S. (2017b). Working capital management and corporate performance: Evidence from Sri Lankan listed manufacturing firms. International Journal of Accounting and Financial Reporting, 7(2), 577-591. https://doi.org/10.5296/ijafr.v7i2.12453

Vural, G., Sökmen, A. G., \& Çetenak, E. H. (2012). Affects of working capital management on firm's performance: evidence from Turkey. International Journal of Economics and Financial Issues, 2(4), 488-495. Retrieved from http://dergipark.org.tr/ijefi/issue/31955/351866

Wasiuzzaman, S. (2015). Working capital and firm value in an emerging market. International Journal of Managerial Finance, 11(1), 60-79. https://doi.org/10.1108/IJMF-01-2013-0016.

Wilner, B. S. (2000). The exploitation of relationship in financial distress: The case of trade credit. Journal of Finance, 55, 153-178. https://doi.org/10.1111/0022-1082.00203 